\title{
Clinicopathological significance of DAPK promoter methylation in non-small-cell lung cancer: a systematic review and meta-analysis
}

This article was published in the following Dove Press journal: Cancer Management and Research

\author{
Yan Zhangl,* \\ Jiang $\mathrm{Wu}^{1}, *$ \\ Gui Huang' \\ Shouming $\mathrm{Xu}^{2}$ \\ 'Department of Pathology, Huaihe \\ Hospital, Henan University; ${ }^{2}$ School \\ of Life Sciences, Henan University, \\ Kaifeng 475004, People's Republic of \\ China
}

*These authors contributed equally to this work

Correspondence: Shouming Xu School of Life Sciences, Henan University, Jinming St, Kaifeng 475004, China Email shouming.xu99@gmail.com
Background: Lung carcinogenesis is related to silencing of tumor suppressor genes and activation of oncogenes. The aim was to investigate the significance of death-associated protein kinase (DAPK) methylation in non-small-cell lung cancer (NSCLC) through a meta-analysis. Methods: A detailed literature search was made in PubMed, Embase, and Web of Science databases. All analysis was performed with Review Manager 5.2.

Results: In total, 28 studies with a total of 2,148 patients were involved. The frequency of DAPK promoter hypermethylation was $40.50 \%$ in NSCLC, significantly higher than in nonmalignant lung tissue; the pooled OR was 5.69, $P<0.00001$. Additionally, DAPK promoter hypermethylation was significantly correlated with poor overall survival in patients with NSCLC. However, there was no significant difference found while comparing the rate of DAPK promoter hypermethylation in adenocarcinoma and squamous cell cancer. The rate of DAPK promoter hypermethylation was similar between stage III/IV and stage I/II. In addition, the data showed that DAPK promoter hypermethylation was not associated with smoking behavior in patients with NSCLC.

Conclusion: DAPK promoter hypermethylation is correlated with risk of NSCLC and is a potential biomarker for prediction of poor prognosis in patients with NSCLC.

Keywords: DAPK, NSCLC, biomarker, methylation, adenocarcinoma, squamous cell cancer, drug target

\section{Background}

Lung cancer is the second most commonly diagnosed malignancy in men and the third most commonly diagnosed malignancy in women worldwide. ${ }^{1}$ Lung cancer can be classified two major histological groups: small cell lung cancer and non-smallcell lung cancer (NSCLC). NSCLC accounts for more than $80 \%$ of all lung cancers, whereas $15 \%-20 \%$ is small cell lung cancer. ${ }^{2,3}$ NSCLC includes adenocarcinoma (ADC), squamous cell carcinoma (SCC), and large-cell carcinoma, within them, ADC accounts for $40 \%$, SCC for $25 \%-30 \%$, and large-cell carcinoma for $10 \%-15 \%{ }^{4,5}$ Lung carcinogenesis is related to silencing of tumor suppressor genes and activation of oncogenes. Accumulating data indicate that hypermethylation in $\mathrm{CpG}$-rich promoter regions of many suppressor genes can contribute to the development and progression of a variety of cancers. ${ }^{6,7}$

Deiss and Kimchi discovered a large group of new genes by using "technical knock-out (TKO) and rescue" screen. ${ }^{8}$ Those genes function as positive mediators 
of cell death pathways, therefore they were named "DeathAssociated Protein or DAP genes. ${ }^{9}$ One of the genes isolated by the TKO approach encoded a calcium calmodulin regulated serine/threonine kinase and was named DAP kinase (DAPk1 or DAPK). ${ }^{10,11}$ Further investigation indicated that DAPK plays an important role in apoptotic and autophagic cell death, ${ }^{12-14}$ tumor progression suppression, and metastasis suppression. ${ }^{15-19}$ Last two decades, a number of studies showed that DAPK loss by its promoter hypermethylation was associated with the development and progression of NSCLC. However, the results from individual studies were inconsistent due to small size of samples. In the present study, 28 relevant studies were pooled, and a meta-analysis was performed to evaluate the clinicopathological significance of DAPK promoter hypermethylation in NSCLC.

\section{Methods}

\section{Search strategy and selection criteria}

The following electronic databases were screened for relevant articles without any language restrictions: PubMed (1966-2018), Embase (1980-2018), Web of Science (1945-2018), Cochrane Library Database (1972-2018). We used the following keywords: "DAPK methylation", "NSCLC", "Non-small-cell lung cancer", and "lung cancer". A search of PubMed yielded 65 articles, Embase yielded 101, and Web Science yielded 138 articles. The included criteria were as follows: (1) the association between DAPK methylation and the clinicopathological significance of NSCLC; (2) the association of DAPK and prognosis in patients with NSCLC. After screening by titles and abstracts, 38 relevant articles were included for full text review. The following exclusion criteria were used: (1) the same population or overlapping database; (2) conference abstracts containing insufficient data reviews, editorials, letters, case reports, and expert opinion; (3) the studies utilized cell lines. After evaluation, 28 articles fulfilled the entry criteria of this meta-analysis. The detailed information of 28 relevant articles was listed in Table 1.

\section{Data extraction and study assessment}

Two reviewers (YZ and JW) extracted data from selected studies independently by using a standardized data extraction form including the following items: first author's name, year of publication, country, number of patients, histology, stage of NSCLC, smoking status of patients with NSCLC, method for methylation detection. Any disagreement was discussed and reached a consensus for all issues.

\section{Statistical analysis}

ORs with $95 \%$ confidence intervals (CIs) were calculated by using a fixed or random effect model depending on heterogeneity (a fixed effect model for $P^{2}<50 \%$, a random effect model for $I^{2}>50 \%$ ). The analysis was performed to compare DAPK promoter hypermethylation between NSCLC and normal tissue, DAPK promoter hypermethylation in different stage of NSCLC, DAPK promoter hypermethylation in different histology type of NSCLC, as well as in smoker and nonsmoker patients with NSCLC. All $P$-values were two sided. $P$-value less than 0.05 was considered statistically significant. Funnel plots were used for detection of publication bias. All analysis was performed with Review Manager 5.2.

\section{Results}

In total, 28 studies were included in the present study after screening 304 articles by two reviewers (Figure 1). The following items were collected from each study: first author, published year, country, histology of NSCLC, and DAPK hypermethylation status, smoking status as well as patient prognosis (Table 1).

The total number of NSCLC tumor from 28 studies is 2148,870 of them were with DAPK promoter hypermethylated, the rate was $40.50 \%$. Whereas the promoter hypermethylation rate from individual study ranged from $10.99 \%$ to $83.13 \%$ (Table 1). The frequency of DAPK promoter hypermethylation was significantly higher in NSCLC than in non-malignant lung; and the pooled OR was 5.69 with 95\% CI 3.44-9.39, $Z=6.79, P<0.00001$ (Figure 2). DAPK promoter methylation was similar between SCC and ADC; the pooled OR was 1.30 with $95 \%$ CI $0.96-1.74, Z=1.71$, $P=0.09, I^{2}=0 \%$ (Figure 3 ). In addition, DAPK methylation was not significantly correlated with stages of NSCLC; OR was 0.78 with $95 \%$ CI $0.54-1.13, Z=1.29, P=0.20, I^{2}=0 \%$ (Figure 4 ). The rate of DAPK methylation was not associated with smoking behavior in patients with NSCLC; OR was 1.11 with $95 \%$ CI $0.80-1.54, Z=0.62, P=0.53, I^{2}=18 \%$ (Figure 5). However, DAPK promoter hypermethylation was significantly associated with poor prognosis in patients with NSCLC; HR was 1.25 with 95\% CI 1.06-1.46, $Z=2.68$, $P=0.007, I^{2}=0 \%$ (Figure 6).

The quality of each study was assessed using the Newcastle Ottawa Quality Assessment Scale (NOQAS). This scale for non-randomized case controlled studies and cohort studies was used to allocate a maximum of nine points for the quality of selection, comparability, exposure, and outcomes for study participants. Of the studies, 15 scored eight points, 
Table I Main characteristics of included studies

\begin{tabular}{|c|c|c|c|c|c|c|c|c|c|c|c|c|}
\hline \multirow[t]{2}{*}{ Study } & \multirow[t]{2}{*}{ Year } & \multirow[t]{2}{*}{ Country } & \multirow{2}{*}{$\begin{array}{l}\text { Sample } \\
\text { size } \\
(M / T)\end{array}$} & \multirow{2}{*}{$\begin{array}{l}\text { DAPK } \\
\text { methylation } \\
\text { rate (\%) }\end{array}$} & \multicolumn{3}{|c|}{ Histology } & \multicolumn{2}{|c|}{ Stage (TNM) } & \multicolumn{2}{|c|}{ Smoking status } & \multirow[t]{2}{*}{ Method } \\
\hline & & & & & NCT & $A C$ & SCC & I+II & III+IV & + & - & \\
\hline Ali et $\mathrm{al}^{28}$ & 2017 & India & $133 / 160$ & 83.13 & $49 / 70$ & - & - & - & - & - & - & MSP \\
\hline Jin et $\mathrm{al}^{29}$ & 2016 & China & $120 / 199$ & 60.30 & - & $55 / 95$ & $65 / 104$ & - & - & $94 / 145$ & $26 / 54$ & MSP \\
\hline Guo et $\mathrm{al}^{30}$ & 2015 & China & $35 / 202$ & 17.33 & - & $15 / 111$ & $20 / 91$ & $16 / 100$ & $5 / 27$ & - & - & MSP \\
\hline Kontic et $\mathrm{a}^{31}$ & 2012 & Serbia & $11 / 47$ & 23.40 & - & $4 / 18$ & $7 / 29$ & $10 / 35$ & $2 / 18$ & $\mathrm{I} / \mathrm{I}$ & $11 / 44$ & MSP \\
\hline Fujii et $a^{32}$ & 2012 & Japan & $6 / 46$ & 13.04 & $0 / 25$ & - & - & - & - & - & - & MSP \\
\hline Zhang et $\mathrm{al}^{33}$ & 2011 & China & $120 / 200$ & 61.00 & $23 / 200$ & - & - & - & - & - & - & MSP \\
\hline Zhang et $\mathrm{al}^{34}$ & 2010 & China & $11 / 78$ & 14.10 & $3 / 78$ & - & - & - & - & - & - & MSP \\
\hline Jin et $\mathrm{al}^{35}$ & 2010 & China & $88 / 150$ & 58.67 & $15 / 150$ & - & - & - & - & - & - & MSP \\
\hline Peng et $\mathrm{al}^{36}$ & 2010 & China & $48 / 82$ & 58.54 & $0 / 25$ & - & - & - & - & - & - & MSP \\
\hline Niklinska et al ${ }^{37}$ & 2009 & Japan & $22 / 61$ & 36.07 & - & - & - & - & - & - & - & MSP \\
\hline Han et $\mathrm{al}^{38}$ & 2009 & USA & $8 / 14$ & 57.14 & $4 / 20$ & - & - & - & - & - & - & MSP \\
\hline Licchesi et $\mathrm{al}^{39}$ & 2008 & USA & $7 / 19$ & 36.8 & $0 / 46$ & & & & & & & MSP \\
\hline Katayama et a $\mathrm{a}^{40}$ & 2007 & Japan & - & & - & - & - & $2 / 8$ & $8 / 26$ & - & - & MSP \\
\hline Yanagawa et $\mathrm{al}^{41}$ & 2007 & Japan & $26 / 101$ & 25.74 & $8 / 101$ & $14 / 62$ & $12 / 39$ & $20 / 75$ & $6 / 26$ & $20 / 73$ & $6 / 28$ & MSP \\
\hline Liu et $a^{42}$ & 2007 & China & $40 / 122$ & 32.79 & - & $25 / 72$ & $15 / 50$ & $17 / 54$ & $17 / 54$ & $28 / 81$ & $|2 / 4|$ & MSP \\
\hline Belinsky et $\mathrm{al}^{43}$ & 2007 & USA & $22 / 72$ & 30.56 & $5 / 25$ & - & - & - & - & - & - & MSP \\
\hline Fischer et $\mathrm{al}^{44}$ & 2007 & Germany & - & & - & - & - & - & - & - & - & MSP \\
\hline Kim et $\mathrm{al}^{45}$ & $2005 a$ & Korea & $23 / 72$ & 31.94 & $4 / 72$ & - & - & - & - & - & - & MSP \\
\hline de Fraipont et $\mathrm{al}^{46}$ & 2005 & France & - & & - & - & - & - & - & $|8 /| 2 \mid$ & $1 / 4$ & MSP \\
\hline Safar et al ${ }^{47}$ & 2005 & USA & $12 / 32$ & 37.50 & $6 / 32$ & - & - & $16 / 48$ & $8 / 57$ & - & - & MSP \\
\hline Russo et $\mathrm{al}^{48}$ & 2005 & USA & $22 / 49$ & 44.90 & $1 / 27$ & - & - & - & - & - & - & MSP \\
\hline Kim et $\mathrm{al}^{49}$ & $2005 b$ & Korea & - & & - & $13 / 42$ & $7 / 17$ & $9 / 34$ & $9 / 27$ & - & - & MSP \\
\hline Fujiwara et al $\left.\right|^{50}$ & 2005 & Japan & $10 / 9 \mid$ & 10.99 & $5 / 100$ & - & - & $6 / 60$ & $4 / 31$ & $9 / 43$ & $10 / 38$ & MSP \\
\hline Divine et $\mathrm{a}^{51}$ & 2005 & USA & $72 / 206$ & 34.95 & - & - & - & - & - & $16 / 45$ & $45 / 125$ & MSP \\
\hline Lu et $\mathrm{al}^{19}$ & 2004 & USA & - & & - & - & - & - & - & - & - & MSP \\
\hline Toyooka et al ${ }^{52}$ & 2003 & USA & $14 / 38$ & 36.84 & $1 / 15$ & $8 / 20$ & $6 / 18$ & - & - & - & - & COBRA \\
\hline Soria et $\mathrm{a}^{53}$ & 2002 & USA & - & & - & - & - & - & - & $13 / 89$ & $4 / 11$ & MSP \\
\hline $\begin{array}{l}\text { Zöchbauer-Müller } \\
\text { et al }{ }^{54}\end{array}$ & 2001 & Australia & $20 / 107$ & 18.69 & $6 / 104$ & $7 / 45$ & $9 / 43$ & $17 / 82$ & $3 / 25$ & $18 / 98$ & $2 / 9$ & MSP \\
\hline
\end{tabular}

Abbreviations: ADC, adenocarcinoma; COBRA, combined bisulfite restriction analysis; DAPK, death-associated protein kinase; M, number of NSCLC with methylation; MSP, methylation-specific PCR; NCT, normal control tissue; NSCLC, non-small-cell lung cancer; SCC, squamous cell cancer; T, total number of NSCLC.

11 scored seven points, and two scored six points (data not shown). Hence, the studies were of a relatively high quality. A sensitivity analysis, in which one study was removed at a time, was conducted to assess the result stability. The pooled ORs were not significantly changed, indicating the stability of our analyses (data not shown). The funnel plots were largely symmetric (Figure 7), suggesting there were no publication biases in the meta-analysis of DAPK promoter hypermethylation and clinicopathological features.

\section{Discussion}

Aberrant methylation in tumor suppressor genes has been linked to carcinogenesis. Hypermethylation is the predominant mechanism to make tumor suppressor genes silent by promoter inactivation. DAPK gene is located on chromosome 9q34.1. It encodes a proapoptotic protein involved in apoptosis initiated by THN- $\alpha$, IFN- $\gamma$, Fas, and TRAIL. DAPK promoter methylation has been observed in about 30 types of tumor including NSCLC. Moreover, aggressiveness of malignant tumors has been associated with the methylation of the promoter region of the DAPK gene and loss of DAPK expression. ${ }^{20} \mathrm{~A}$ number of studies evaluated the methylation rate in NSCLC, which ranged from $10.99 \%$ to $83.33 \%$ due to small size of samples. We pooled 28 studies including 2,148 NSCLC patients, 870 of them were with DAPK gene promoter hypermethylated; hypermethylation rate was $40.50 \%, 5.69$ times higher than the one in non-malignant lung tissue. Therefore, DAPK promoter hypermethylation was correlated with the risk of NSCLC. Previous evidence indicated that the expression of DAPK was partially restored by treatment with a demethylation agent, $5^{\prime}$-aza-2'-deoxycitidine. ${ }^{15}$ DAPK could be a potential target for development of new strategy of treatment.

We did not find significant association of DAPK promoter hypermethylation with tumor histology, smoking, 


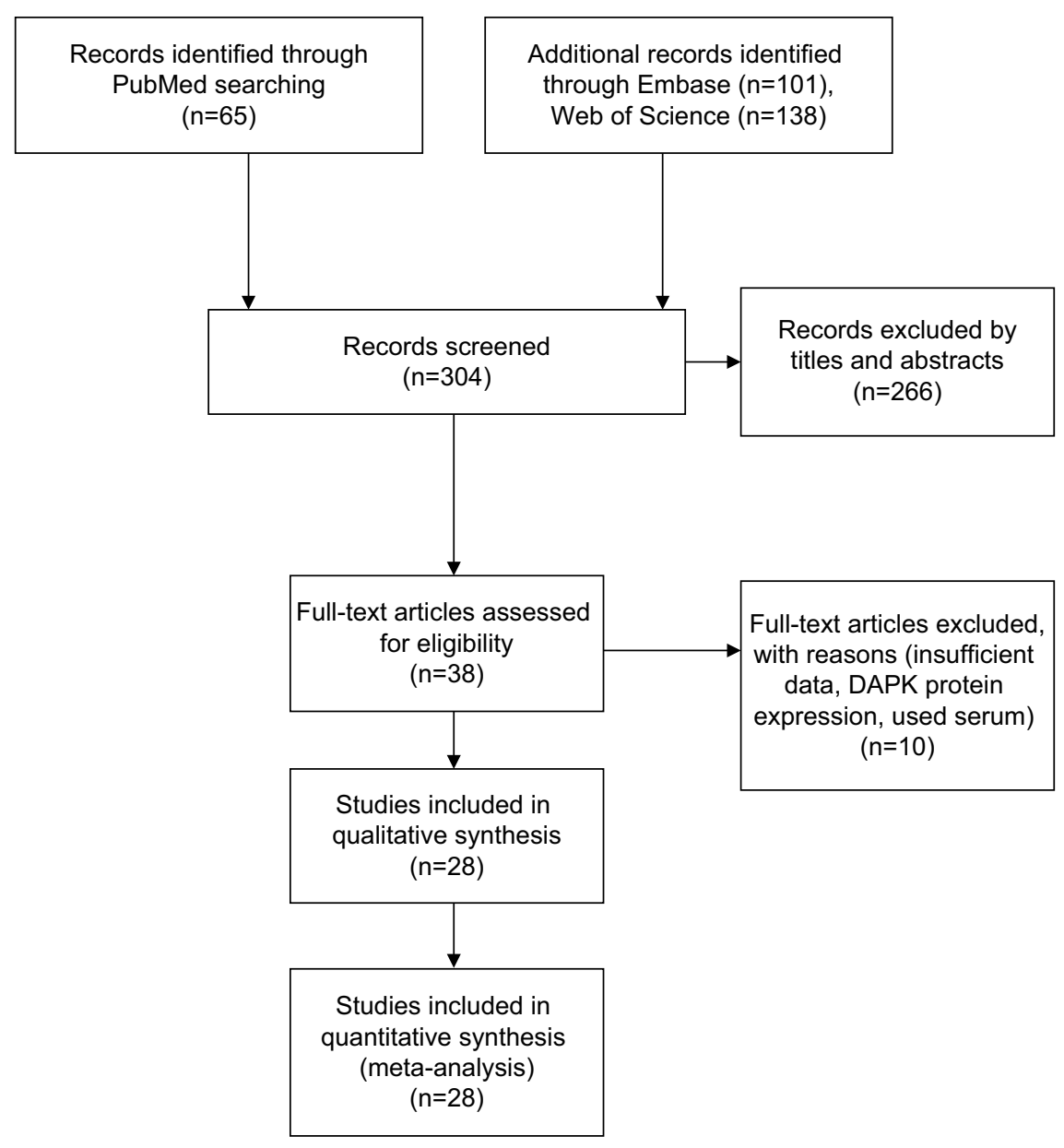

Figure I Schematic flow diagram for selection of included studies.

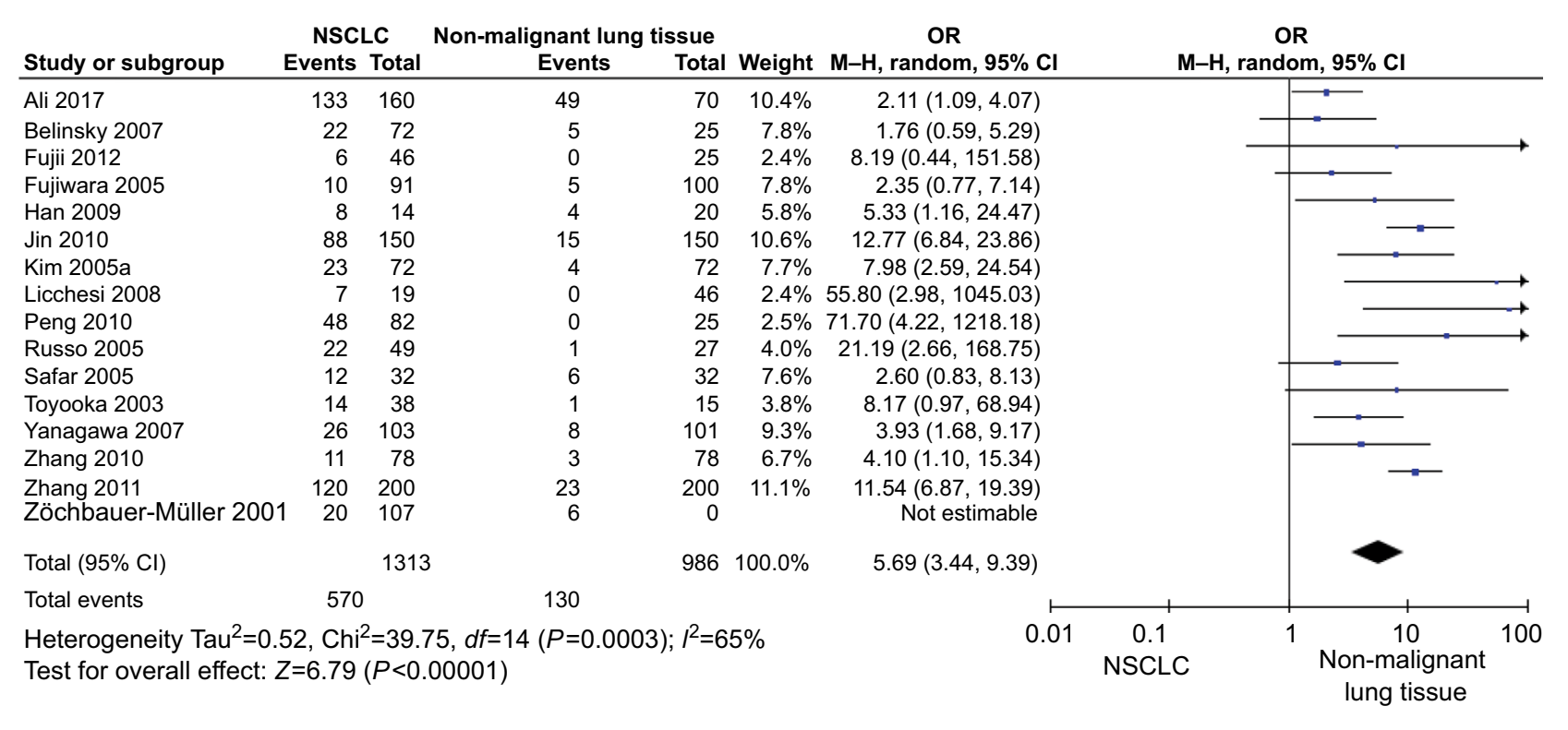

Figure 2 Forest plot for DAPK promoter hypermethylation in NSCLC and non-malignant lung tissue.

Notes: The squares represent the weight of individual study in the meta-analysis, the line width indicates the corresponding $95 \% \mathrm{Cl}$, the diamond represents the pooled $\mathrm{OR}$, and the width of diamond indicates $95 \% \mathrm{Cl}$.

Abbreviations: DAPK, death-associated protein kinase; M-H, Mantel-Haenszel; NSCLC, non-small-cell lung cancer. 
Study or subgroup

Guo 2015

Jin 2016

Kim 2005b

Kontic 2012

Liu 2007

Niklinska 2009

Toyooka 2003

Yanagawa 2007

Zöchbauer-Müller 2001

Total $(95 \% \mathrm{Cl})$

Total events

Heterogeneity: $\mathrm{Chi}^{2}=3.89, d f=8(P=0.87) ; l^{2}=0 \%$

Test for overall effect: $Z=1.71(P=0.09)$
SCC ADC OR

Events Total Events Total Weight $\mathrm{M}-\mathrm{H}$, fixed, $95 \% \mathrm{CI}$

$\begin{array}{rrrrrr}20 & 91 & 15 & 111 & 13.8 \% & 1.80(0.86,3.77)\end{array}$

$\begin{array}{llllll}65 & 104 & 55 & 95 & 28.2 \% & 1.21(0.69,2.14)\end{array}$

$\begin{array}{llllll}7 & 17 & 13 & 42 & 5.8 \% & 1.56(0.49,5.01)\end{array}$

$\begin{array}{llllll}7 & 29 & 4 & 18 & 4.9 \% & 1.11(0.27,4.51)\end{array}$

$\begin{array}{llllll}15 & 50 & 25 & 72 & 18.8 \% & 0.81(0.37,1.75)\end{array}$

$\begin{array}{llllll}17 & 41 & 5 & 20 & 5.1 \% & 2.13(0.65,6.97)\end{array}$

$\begin{array}{llllll}6 & 18 & 8 & 20 & 6.6 \% & 0.75(0.20,2.83)\end{array}$

$\begin{array}{llllll}12 & 39 & 14 & 62 & 9.8 \% & 1.52(0.62,3.76)\end{array}$

$\begin{array}{llllll}9 & 43 & 7 & 45 & 7.1 \% & 1.44(0.48,4.28)\end{array}$

$432 \quad 485 \quad 100.0 \% \quad 1.30(0.96,1.74)$ 146

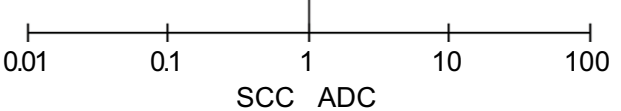

Figure 3 Forest plot for DAPK promoter hypermethylation in SCC and ADC.

Notes: The squares represent the weight of individual study in the meta-analysis, the line width indicates the corresponding $95 \% \mathrm{Cl}$, the diamond represents the pooled $\mathrm{OR}$, and the width of diamond indicates $95 \% \mathrm{Cl}$.

Abbreviations: ADC, adenocarcinoma; DAPK, death-associated protein kinase; M-H, Mantel-Haenszel; NSCLC, non-small-cell lung cancer; SCC, squamous cell carcinoma.

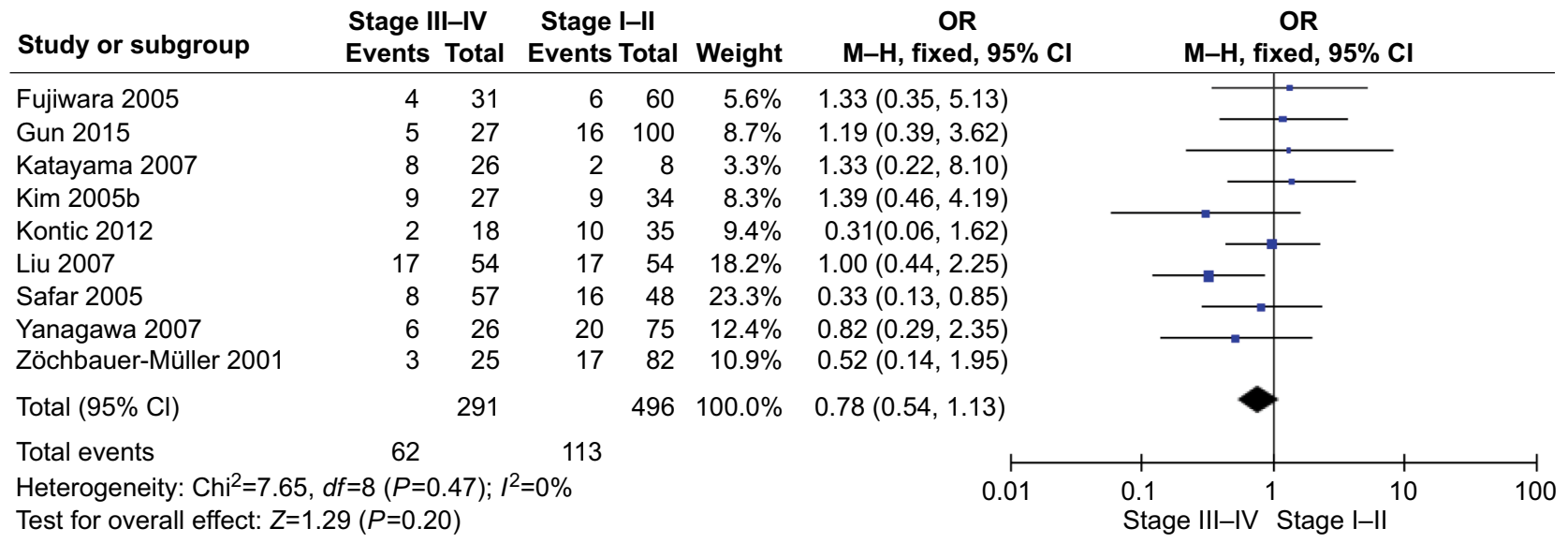

Figure 4 Forest plot for DAPK promoter hypermethylation in NSCLC stage III/IV and stage I/II.

Notes: The squares represent the weight of individual study in the meta-analysis, the line width indicates the corresponding $95 \% \mathrm{Cl}$, the diamond represents the pooled $\mathrm{OR}$, and the width of diamond indicates $95 \% \mathrm{Cl}$.

Abbreviations: DAPK, death-associated protein kinase; M-H, Mantel-Haenszel; NSCLC, non-small-cell lung cancer.

Smoking Non smoking OR

Study or subgroup

Events Total Events Total Weight $\mathrm{M}-\mathrm{H}$, fixed, $95 \% \mathrm{Cl}$

OR

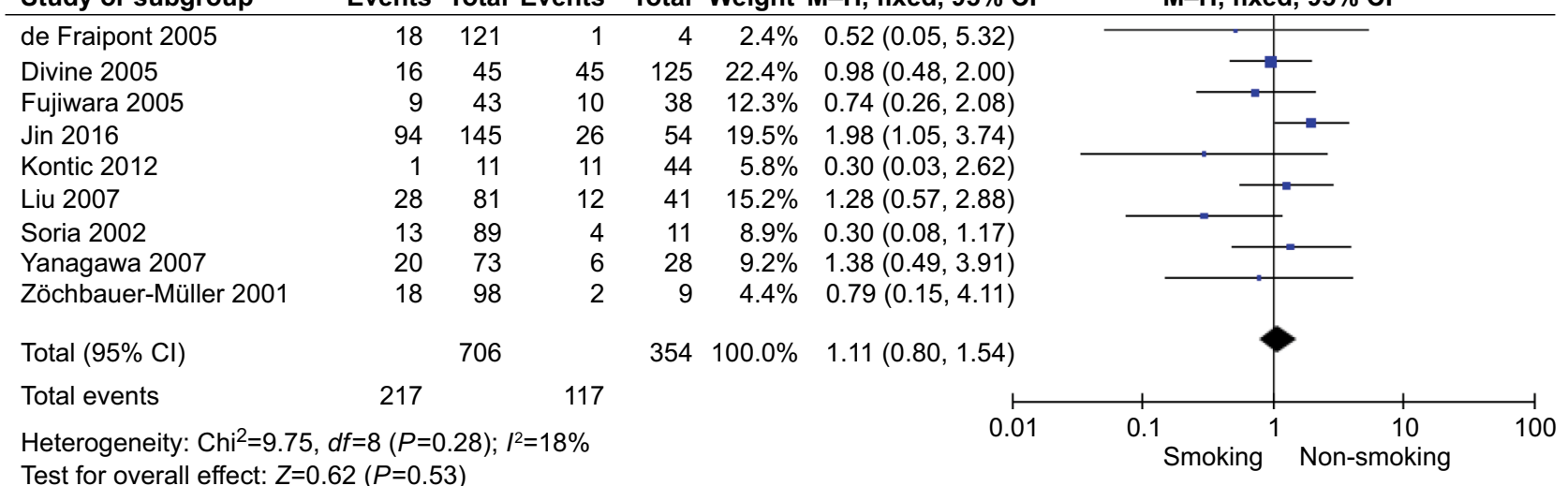

Test for overall effect: $Z=0.62(P=0.53)$

Figure 5 Forest plot for DAPK promoter hypermethylation in NSCLC patients with smoking and non-smoking behavior.

Notes: The squares represent the weight of individual study in the meta-analysis, the line width indicates the corresponding $95 \% \mathrm{Cl}$, the diamond represents the pooled $\mathrm{OR}$, and the width of diamond indicates $95 \% \mathrm{Cl}$.

Abbreviations: M-H, Mantel-Haenszel; NSCLC, non-small-cell lung cancer. 


\begin{tabular}{|c|c|c|c|c|c|c|c|}
\hline Study or subgroup & $\log (H R)$ & SE & Weight & $\begin{array}{c}\text { HR } \\
\text { IV, fixed, } 95 \% \mathrm{CI}\end{array}$ & \multicolumn{2}{|c|}{$\begin{array}{c}\text { HR } \\
\text { IV, fixed, } 95 \% \mathrm{Cl}\end{array}$} & \\
\hline Fischer 2007 & 0.1944 & 0.3175 & $6.7 \%$ & $1.21(0.65,2.26)$ & - & fo- & \\
\hline Katayama 2007 & 1.7405 & 0.8181 & $1.0 \%$ & $5.70(1.15,28.33)$ & & & \\
\hline Kim 2005a & 0.1944 & 0.4864 & $2.9 \%$ & $1.21(0.47,3.15)$ & & & \\
\hline Lu 2004 & 0.2279 & 0.0914 & $81.1 \%$ & $1.26(1.05,1.50)$ & & & \\
\hline Niklinska 2009 & 0.2856 & 0.5401 & $2.3 \%$ & $1.33(0.46,3.84)$ & & & \\
\hline Safar 2005 & -0.174 & 0.446 & $3.4 \%$ & $0.84(0.35,2.01)$ & & - & \\
\hline Yanagawa 2007 & -0.0555 & 0.516 & $2.5 \%$ & $0.95(0.34,2.60)$ & & & \\
\hline Total $(95 \% \mathrm{Cl})$ & & & $100.0 \%$ & $1.25(1.06,1.46)$ & & $\nabla$ & \\
\hline $\begin{array}{l}\text { Heterogeneity: } \mathrm{Chi}^{2}= \\
\text { Test for overall effect }\end{array}$ & $\begin{array}{l}1.55, d f=6(P=0.60) \\
Z=2.68(P=0.007)\end{array}$ & $I^{2}=0 \%$ & & 0.01 & $\begin{array}{l}0.1 \\
\text { Methylation }\end{array}$ & 10 & $\overrightarrow{100}$ \\
\hline
\end{tabular}

Figure 6 Forest plot for the association of DAPK promoter hypermethylation and the overall survival of NSCLC patients.

Notes: The squares represent the weight of individual study in the meta-analysis, the line width indicates the corresponding $95 \% \mathrm{Cl}$, the diamond represents the pooled $\mathrm{OR}$, and the width of diamond indicates $95 \% \mathrm{Cl}$.

Abbreviations: DAPK, death-associated protein kinase; NSCLC, non-small-cell lung cancer; SE, standard error.

A

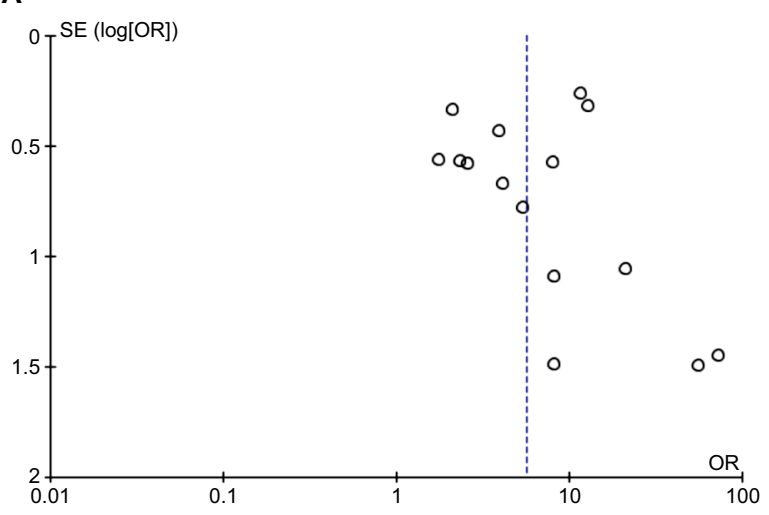

C

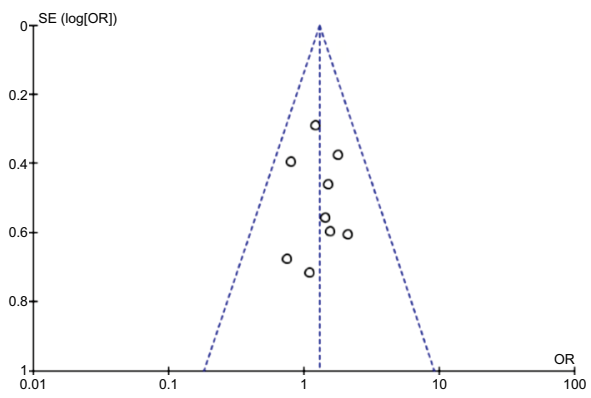

B

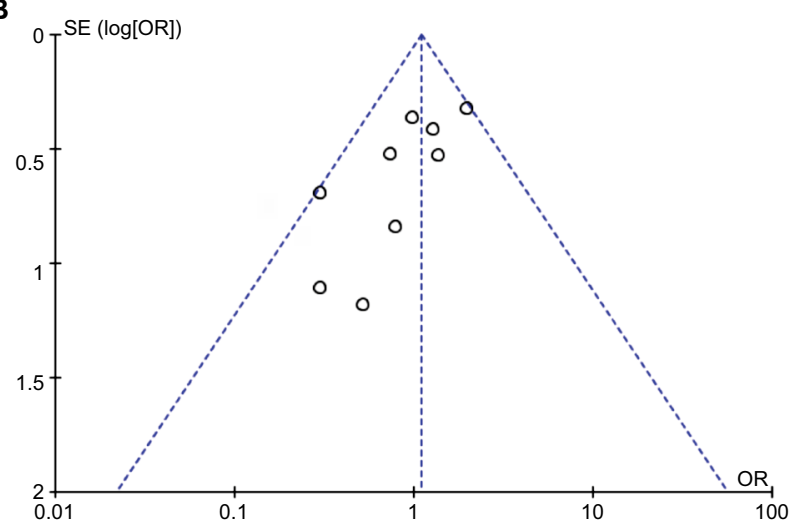

E
D

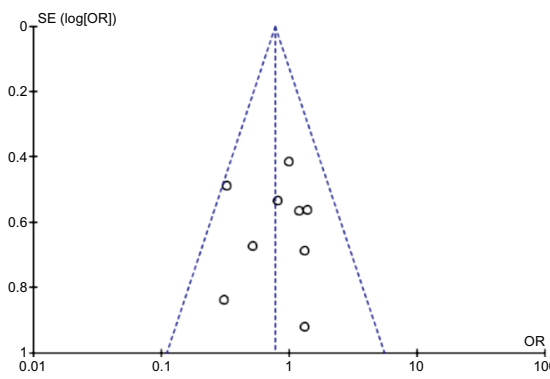

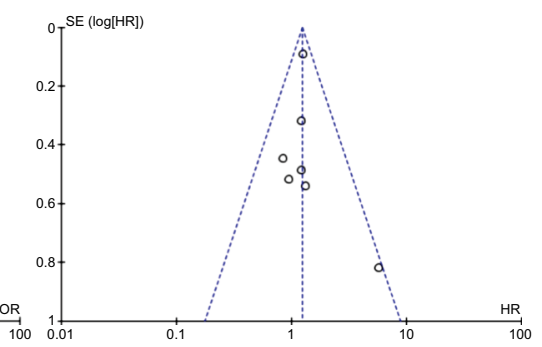

Figure 7 Funnel plot for publication bias.

Notes: (A) DAPK promoter hypermethylation in NSCLC and non-malignant lung tissue; (B) DAPK promoter hypermethylation in SCC and ADC; (C) DAPK promoter hypermethylation in NSCLC stage III/IV and stage I/II. (D) DAPK promoter hypermethylation in NSCLC patients with smoking and non-smoking behavior; (E) the association of DAPK promoter hypermethylation and the overall survival of NSCLC patients. Area of the circle represents the weight of individual study.

Abbreviations: ADC, adenocarcinoma; DAPK, death-associated protein kinase; NSCLC, non-small-cell lung cancer; SCC, squamous cell carcinoma; SE, standard error.

and stage. Although TNM staging system still remained the most powerful tool for medical decision making, it is difficult to accurately predict the prognosis for individual patient. The 5-year survival rate for patients with stage I NSCLC is about $65 \%-80 \%,{ }^{21}$ therefore a more accurate tool, independent from TNM stage, is very important to predict prognosis in those patients. Our finding indicated that DAPK was correlated to worse survival in our metaanalysis, supporting the importance of epigenetic gene regulation in NSCLC progression and prognosis. Loss of apoptotic functions would compromise cell death induced by unrepaired DNA damage..$^{22}$ In addition, DAPK 
promoter hypermethylation is associated with metastatic status. Taken together, DAPK promoter hypermethylation leads to worse prognosis in patients with NSCLC. DAPK hypermethylation is a potential predictor of survival in patients with NSCLC.

Given the important role of smoking in the development of lung cancer and the fact that DNA methylation is an early event in carcinogenesis, ${ }^{23}$ several biomarker such as Wnt inhibitory factor-1 (Wif1), Phosphatase and tensin homologue deleted on chromosome 10 (PTEN), and TP53 were associated with smoking behavior. ${ }^{24-27}$ However, no correlation was found between DAPK promoter hypermethylation and the smoking behavior in the present study. Further confirmation needs to be finished in future when more relative studies are available.

Our findings should be interpreted in view of certain limitations. First, most of the included studies were retrospective, 26 out of 28 were of sufficient quality (NOQAS $\geq 7$ ). Hence, the studies were of a relatively high quality. Although the possibility of selection, sample, and publication bias could not be excluded, no obvious bias was detected by the funnel plots. Second, present findings were based on individual unadjusted ORs and further confirmation needs to be finished by evaluation adjusted with other potential risk factors.

\section{Conclusion}

In summary, present findings suggested that DAPK promoter hypermethylation was correlated with the risk of NSCLC; and DAPK is a promising drug target for development of new therapy strategy. Additionally, DAPK promoter hypermethylation was a potential predictor of poor prognosis in patients with NSCLC.

\section{Data sharing statement}

The datasets analyzed during the current study are available from the corresponding author on reasonable request.

\section{Author contributions}

All authors contributed toward data analysis, drafting and revising the paper and agree to be accountable for all aspects of the work. The corresponding author had full access to all data and the final responsibility for the decision to submit the article for publication. All authors read and approved the final manuscript.

\section{Disclosure}

The authors report no conflicts of interest in this work.

\section{References}

1. Global Burden of Disease Cancer Collaboration; Fitzmaurice C, Allen $\mathrm{C}$, et al. Global, regional, and national cancer incidence, mortality, years of life lost, years lived with disability, and disability-adjusted life-years for 32 cancer groups, 1990 to 2015: a systematic analysis for the global burden of disease study. JAMA Oncol. 2017;3(4):524-548.

2. Siegel RL, Miller KD, Jemal A. Cancer statistics, 2016. CA Cancer J Clin. 2016;66(1):7-30.

3. Herbst RS, Heymach JV, Lippman SM. Lung cancer. $N$ Engl J Med. 2008;359(13):1367-1380.

4. Reck M, Popat S, Reinmuth N, et al. Metastatic non-small-cell lung cancer (NSCLC): ESMO clinical practice guidelines for diagnosis, treatment and follow-up. Ann Oncol. 2014;25 Suppl 3:iii27-iii39.

5. Thakur MK, Wozniak AJ. Spotlight on necitumumab in the treatment of non-small-cell lung carcinoma. Lung Cancer. 2017;8:13-19.

6. Baylin SB, Esteller M, Rountree MR, Bachman KE, Schuebel K, Herman JG. Aberrant patterns of DNA methylation, chromatin formation and gene expression in cancer. Hum Mol Genet. 2001;10(7):687-692.

7. Baylin SB, Herman JG, Graff JR, Vertino PM, Issa JP. Alterations in DNA methylation: a fundamental aspect of neoplasia. Adv Cancer Res. 1998;72:141-196.

8. Deiss LP, Kimchi A. A genetic tool used to identify thioredoxin as a mediator of a growth inhibitory signal. Science. 1991;252(5002):117-120.

9. Kimchi A. DAP genes: novel apoptotic genes isolated by a functional approach to gene cloning. Biochim Biophys Acta. 1998;1377(2): F13-F33.

10. Deiss LP, Feinstein E, Berissi H, Cohen O, Kimchi A. Identification of a novel serine/threonine kinase and a novel $15-\mathrm{kD}$ protein as potential mediators of the gamma interferon-induced cell death. Genes Dev. 1995;9(1):15-30.

11. Gozuacik D, Kimchi A. DAPk protein family and cancer. Autophagy. 2006;2(2):74-79.

12. Kögel D, Reimertz C, Düssmann H, Mech P, Scheidtmann KH, Prehn $\mathrm{JH}$. The death associated protein (DAP) kinase homologue Dlk/ZIP kinase induces p19ARF- and p53-independent apoptosis. Eur J Cancer. 2003;39(2):249-256.

13. Inbal B, Bialik S, Sabanay I, Shani G, Kimchi A. DAP kinase and DRP-1 mediate membrane blebbing and the formation of autophagic vesicles during programmed cell death. $J$ Cell Biol. 2002;157(3):455-468.

14. Pattingre S, Tassa A, Qu X, et al. Bcl-2 antiapoptotic proteins inhibit Beclin 1-dependent autophagy. Cell. 2005;122(6):927-939.

15. Kissil JL, Feinstein E, Cohen O, et al. DAP-kinase loss of expression in various carcinoma and B-cell lymphoma cell lines: possible implications for role as tumor suppressor gene. Oncogene. 1997;15(4):403-407.

16. Lehmann U, Celikkaya G, Hasemeier B, Länger F, Kreipe H. Promoter hypermethylation of the death-associated protein kinase gene in breast cancer is associated with the invasive lobular subtype. Cancer Res. 2002;62(22):6634-6638.

17. Lévy D, Plu-Bureau G, Decroix Y, et al. Death-associated protein kinase loss of expression is a new marker for breast cancer prognosis. Clin Cancer Res. 2004;10(9):3124-3130.

18. Kim DH, Nelson HH, Wiencke JK, et al. Promoter methylation of DAP-kinase: association with advanced stage in non-small cell lung cancer. Oncogene. 2001;20(14):1765-1770.

19. Lu C, Soria JC, Tang X, et al. Prognostic factors in resected stage I non-small-cell lung cancer: a multivariate analysis of six molecular markers. J Clin Oncol. 2004;22(22):4575-4583.

20. Tang X, Khuri FR, Lee JJ, et al. Hypermethylation of the deathassociated protein (DAP) kinase promoter and aggressiveness in stage I non-small-cell lung cancer. J Natl Cancer Inst. 2000;92(18):1511-1516.

21. Bains MS. Surgical treatment of lung cancer. Chest. 1991;100(3): 826-837.

22. Buckingham L, Penfield Faber L, Kim A, et al. PTEN, RASSF1 and DAPK site-specific hypermethylation and outcome in surgically treated stage I and II nonsmall cell lung cancer patients. Int $J$ Cancer. 2010;126(7):1630-1639. 
23. Feng Q, Hawes SE, Stern JE, et al. DNA methylation in tumor and matched normal tissues from non-small cell lung cancer patients. Cancer Epidemiol Biomarkers Prev. 2008;17(3):645-654.

24. Guo H, Zhou S, Tan L, Wu X, Wu Z, Ran R. Clinicopathological significance of WIF1 hypermethylation in NSCLC, a meta-analysis and literature review. Oncotarget. 2017;8(2):2550-2557.

25. Jin G, Kim MJ, Jeon HS, et al. PTEN mutations and relationship to EGFR, ERBB2, KRAS, and TP53 mutations in non-small cell lung cancers. Lung Cancer. 2010;69(3):279-283.

26. Tammemagi MC, Mclaughlin JR, Bull SB. Meta-analyses of p53 tumor suppressor gene alterations and clinicopathological features in resected lung cancers. Cancer Epidemiol Biomarkers Prev. 1999;8(7):625-634.

27. Cancer Genome Atlas Research Network. Comprehensive genomic characterization of squamous cell lung cancers. Nature. 2012;489(7417):519-525.

28. Ali A, Kumar S, Kakaria VK, et al. Detection of promoter DNA methylation of APC, DAPK, and GSTP1 genes in tissue biopsy and matched serum of advanced-stage lung cancer patients. Cancer Invest. 2017;35(6):423-430.

29. Jin Y, Xu P, Liu X, et al. Cigarette smoking, BPDE-DNA adducts, and aberrant promoter methylations of tumor suppressor genes (TSGs) in NSCLC from Chinese population. Cancer Invest. 2016;34(4):173-180.

30. Guo M, Alumkal J, Drachova T, et al. CHFR methylation strongly correlates with methylation of DNA damage repair and apoptotic pathway genes in non-small cell lung cancer. Discov Med. 2015;19(104):151-158.

31. Kontic M, Stojsic J, Jovanovic D, et al. Aberrant promoter methylation of CDH13 and MGMT genes is associated with clinicopathologic characteristics of primary non-small-cell lung carcinoma. Clin Lung Cancer. 2012;13(4):297-303.

32. Fujii M, Fujimoto N, Hiraki A, et al. Aberrant DNA methylation profile in pleural fluid for differential diagnosis of malignant pleural mesothelioma. Cancer Sci. 2012;103(3):510-514.

33. Zhang CY, Jin YT, Xu HY, et al. Relationship between promoter methylation of p16, DAPK and RAR beta genes and the clinical data of non-small cell lung cancer. Zhonghua Yi Xue Yi Chuan Xue Za Zhi. 2011;28(1):23-28.

34. Zhang Y, Wang R, Song H, et al. Methylation of multiple genes as a candidate biomarker in non-small cell lung cancer. Cancer Lett. 2011;303(1): 21-28.

35. Jin $\mathrm{Y}, \mathrm{Xu} \mathrm{H}$, Zhang $\mathrm{C}$, et al. Combined effects of cigarette smoking, gene polymorphisms and methylations of tumor suppressor genes on non small cell lung cancer: a hospital-based case-control study in China. BMC Cancer. 2010;10:422.

36. Peng Z, Shan $C$, Wang $H$. Value of promoter methylation of RASSF1A, p16, and DAPK genes in induced sputum in diagnosing lung cancers. Zhong Nan Da Xue Xue Bao Yi Xue Ban. 2010;35(3):247-253.

37. Niklinska W, Naumnik W, Sulewska A, Kozłowski M, Pankiewicz W, Milewski R. Prognostic significance of DAPK and RASSF1A promoter hypermethylation in non-small cell lung cancer (NSCLC). Folia Histochem Cytobiol. 2009;47(2):275-280.

38. Han W, Wang T, Reilly AA, Keller SM, Spivack SD. Gene promoter methylation assayed in exhaled breath, with differences in smokers and lung cancer patients. Respir Res. 2009;10:86.

39. Licchesi JD, Westra WH, Hooker CM, Herman JG. Promoter hypermethylation of hallmark cancer genes in atypical adenomatous hyperplasia of the lung. Clin Cancer Res. 2008;14(9):2570-2578.
40. Katayama H, Hiraki A, Fujiwara K, et al. Aberrant promoter methylation profile in pleural fluid DNA and clinicopathological factors in patients with non-small cell lung cancer. Asian Pac J Cancer Prev. 2007;8(2):221-224.

41. Yanagawa N, Tamura G, Oizumi H, et al. Promoter hypermethylation of RASSF1A and RUNX3 genes as an independent prognostic prediction marker in surgically resected non-small cell lung cancers. Lung Cancer. 2007;58(1):131-138.

42. Liu Y, Gao W, Siegfried JM, Weissfeld JL, Luketich JD, Keohavong P. Promoter methylation of RASSF1A and DAPK and mutations of K-ras, p53, and EGFR in lung tumors from smokers and never-smokers. BMC Cancer. 2007;7:74.

43. Belinsky SA, Grimes MJ, Casas E, et al. Predicting gene promoter methylation in non-small-cell lung cancer by evaluating sputum and serum. Br J Cancer. 2007;96(8):1278-1283.

44. Fischer JR, Ohnmacht U, Rieger N, et al. Prognostic significance of RASSF1A promoter methylation on survival of non-small cell lung cancer patients treated with gemcitabine. Lung Cancer. 2007;56(1): 115-123.

45. Kim YT, Park SJ, Lee SH, et al. Prognostic implication of aberrant promoter hypermethylation of $\mathrm{CpG}$ islands in adenocarcinoma of the lung. J Thorac Cardiovasc Surg. 2005;130(5):1378-1378.

46. de Fraipont F, Moro-Sibilot D, Michelland S, Brambilla E, Brambilla C, Favrot MC. Promoter methylation of genes in bronchial lavages: a marker for early diagnosis of primary and relapsing non-small cell lung cancer? Lung Cancer. 2005;50(2):199-209.

47. Safar AM, Spencer H, Su X, et al. Methylation profiling of archived non-small cell lung cancer: a promising prognostic system. Clin Cancer Res. 2005;11(12):4400-4405.

48. Russo AL, Thiagalingam A, Pan H, et al. Differential DNA hypermethylation of critical genes mediates the stage-specific tobacco smoke-induced neoplastic progression of lung cancer. Clin Cancer Res. 2005;11(7):2466-2470.

49. Kim YT, Lee SH, Sung SW, Kim JH. Can aberrant promoter hypermethylation of $\mathrm{CpG}$ islands predict the clinical outcome of nonsmall cell lung cancer after curative resection? Ann Thorac Surg. 2005;79(4):1180-1188; discussion 1180-1188.

50. Fujiwara K, Fujimoto N, Tabata M, et al. Identification of epigenetic aberrant promoter methylation in serum DNA is useful for early detection of lung cancer. Clin Cancer Res. 2005;11(3):1219-1225.

51. Divine KK, Pulling LC, Marron-Terada PG, et al. Multiplicity of abnormal promoter methylation in lung adenocarcinomas from smokers and never smokers. Int $J$ Cancer. 2005;114(3):400-405.

52. Toyooka S, Toyooka KO, Miyajima K, et al. Epigenetic down-regulation of death-associated protein kinase in lung cancers. Clin Cancer Res. 2003;9(8):3034-3041.

53. Soria JC, Rodriguez M, Liu DD, Lee JJ, Hong WK, Mao L. Aberrant promoter methylation of multiple genes in bronchial brush samples from former cigarette smokers. Cancer Res. 2002;62(2):351-355.

54. Zöchbauer-Müller S, Fong KM, Virmani AK, Geradts J, Gazdar AF, Minna JD. Aberrant promoter methylation of multiple genes in nonsmall cell lung cancers. Cancer Res. 2001;61(1):249-255.
Cancer Management and Research

\section{Publish your work in this journal}

Cancer Management and Research is an international, peer-reviewed open access journal focusing on cancer research and the optimal use of preventative and integrated treatment interventions to achieve improved outcomes, enhanced survival and quality of life for the cancer patient. The manuscript management system is completely online and includes

\section{Dovepress}

a very quick and fair peer-review system, which is all easy to use. Visit $\mathrm{http}: / / \mathrm{www}$.dovepress.com/testimonials.php to read real quotes from published authors. 